\title{
Penilaian Kinerja Keuangan terhadap Nilai Perusahaan BUMN Bidang Konstruksi yang Terdaftar di Bursa Efek Indonesia
}

\author{
Anggi Angga Resti \\ Program Studi Manajemen, Universitas Pembangunan Nasional Veteran Jakarta \\ Jl. RS Fatmawati No.1 Pondok Labu, Jakarta Selatan, Jakarta, Indonesia \\ anggianggaresti@upnvj.ac.id
}

Diterima: 09-02-2021

Disetujui: 16-06-2021

Dipublikasi: 30-06-2021

\begin{abstract}
ABSTRAK
Penelitian ini bertujuan untuk mengetahui kinerja keuangan terhadap nilai perusahaan BUMN bidang konstruksi yang terdapat di Bursa Efek Indonesia periode 2016-2019. Berdasarkan Surat Keputusan Menteri BUMN Nomor: KEP-100/MBU/2002 tentang Penilaian Tingkat Kesehatan BUMN. Penilaian tingkat kesehatan menggunakan delapan indikator, yaitu ROE (Return On Equity), ROI (Return On Investement), rasio kas, rasio lancar, collection period, perputaran persediaan, perputaran total aset, dan total modal sendiri terhadap total aset. Penelitian ini dilakukan pada empat perusahaan BUMN bidang konstruksi yang terdaftar di Bursa Efek Indonesia periode 20162019. Penelitian ini merupakan jenis penelitian analisis kuantitatif yang menggunakan data sekunder. Dokumen yang diperlukan adalah laporan keuangan tahunan PT. Adhi Karya (Persero) Tbk., PT. Pembangunan Perumahan (Persero) Tbk.,Waskita Karya (Persero) dan Tbk. PT. Wijaya Karya (Persero) Tbk., periode 2016-2019. Berdasarkan hasil penelitian menunjukkan bahwa penilaian kinerja keuangan dan nilai perusahaan BUMN bidang konstruksi yang terdaftar di BEI periode 2016-2019, dengan rincian: (a) kinerja keuangan PT. Adhi Karya Tbk., pada periode 2016-2019, menunjukkan bahwa perusahaan selalu mendapatkan predikat Kurang Sehat kategori BBB; (b) kinerja keuangan PT. Pembangunan Perumahan Tbk., pada periode 2016-2019, menunjukkan bahwa perusahaan mendapat predikat Sehat kategori A pada tahun 2016-2018, dan mendapat predikat Sehat kategori AA pada tahun 2019; (c) kinerja keuangan PT. Waskita Karya Tbk., pada periode 2016-2019, menunjukkan bahwa perusahaan mendapatkan predikat Sehat kategori A pada tahun 2016-2018, dan mendapat predikat Kurang Sehat kategori BB pada tahun 2019; dan (d) kinerja keuangan PT. Wijaya Karya Tbk,.pada periode 2016-2019, menunjukkan bahwa perusahaan selalu mendapatkan predikat Kurang Sehat kategori BBB. (e) Hasil ini terbukti bahwa kinerja keuangan memberikan sinyal terhadap nilai perusahaan.
\end{abstract}

Kata Kunci:

Kinerja Keuangan; Nilai Perusahaan; Surat Keputusan Menteri BUMN Nomor:KEP-100/MBU/2002.

\begin{abstract}
This study aims to determine of the financial performance on firm value of state-owned construction companies listed in the Indonesia Stock Exchange for period 2016-2019 which based on Decree of the Minister of StateOwned Enterprises No: KEP-100/MBU/2002. Assessment of financial healthy used eight indicators, there are ROE (Return On Equity), ROI (Return On Investment), cash ratio, current ratio, collection periods, inventory turnover, total asset turn over, and total equity to total asset. The research is conducted in four constructions state-owned enterprises (SOE) listed in the Indonesia Stock Exchange for the period 2016-2019.The documents required are the annual financial statements of PT. Adhi Karya (Persero) Tbk., PT. Housing Development Tbk., PT. Waskita Karya (Persero) Tbk., and PT. Wijaya Karya (Persero) Tbk., for the period 2016-2019. Based on the results show assessment of the financial performance and firm value of state-owned companies in the construction sector listed on the Indonesia Stock Exchange for the period 2016-2019, with details: (a) financial performance of PT. Adhi Karya Tbk in the 2016-2019 period, showed that the company always received the title of Unhealthy BBB Category; (b) financial performance of PT. Housing Development Tbk in the 2016-2019 period, showed that the company received the title of Healthy Category A in 2016-2018, and received the title of Healthy Category of $A A$ in 2019. (c) financial performance of PT. Waskita Karya Tbk in the 2016-2019 period, showed that the company received the title Healthy Category A in 2016-2018, and received the title of Unhealthy Category BB in 2019. And (d) financial performance of PT. Wijaya Tbk in the 2016-2019 period, showed that the company always
\end{abstract}


received the title of Unhealthy BBB Category. (e) The result of this research signal that financial performance there influence of firm value.

Keywords:

Financial Performance; Firm Value; Decree of the Minister of State-Owned Enterprises No: KEP100/MBU/2002 


\section{PENDAHULUAN}

Pada era pemerintahan Presiden Joko Widodo dan M Jusuf Kalla, pembangunan infrastruktur berkembang sangat pesat. Fokus pembangunan infrastruktur tentunya berkaitan dengan peran BUMN bidang konstruksi dalam mendukung strategi pemerintah (Utamaningsih dan Muharis 2020). Pembangunan infrastruktur diyakini dapat menjadi lokomotif pertumbuhan ekonomi nasional dalam jangka menengah-panjang. Negara-negara dengan pertumbuhan sangat tinggi selalu ditunjang oleh pembangunan infrastruktur secara besar-besaran. Dalam pembangunan infrastruktur Indonesia masih tertinggal karena hal tersebut pemerintah mengambil langkah dengan membangun berbagai mega proyek dalam Proyek Strategis Nasional (PSN). Namun pemerintah memiliki keterbatasan anggaran untuk membiayai infrastruktur. Sebab, berdasarkan target jangka menengah (RPJMN 2015-2019). Pembangunan infrastruktur di Indonesia membutuhkan alokasi anggaran Rp4.796 triliun. Pemerintah hanya mampu menyediakan anggaran Rp1.979 triliun atau 41.3\% dari kebutuhan. Sisanya dibantu oleh pihak swasta dan BUMN. Kondisi tersebut menunjukkan bahwa prospek infrastruktur sangat menjanjikan. (Investor Daily Indonesia 2017). Proyek infrastruktur pemerintah ini juga menjadi faktor yang mendorong perusahaan BUMN terutama bidang konstruksi untuk ikut terlibat di dalam proyek infrastruktur tersebut (Dinarjito 2018).

Aktifitas proyek yang besar dalam pembangunan infrastruktur berdampak positif terhadap kinerja perusahaan konstruksi sehingga dapat membuat para investor melakukan investasi dengan membeli saham-saham perusahaan sebagai bentuk antisipasi terhadap adanya potensi kenaikan kinerja perusahaan konstruksi. Namun fenomena yang terjadi pada nilai perusahaan empat perusahaan konstruksi BUMN go public diukur dengan rasio PBV. Selama tiga tahun pada tahun 2016 sampai dengan 2018 mengalami penurunan dan selanjutnya mengalami kenaikan pada tahun 2019. Penurunan nilai PBV dapat mempengaruhi penurunan kesejahteraan para pemegang saham, jika sebaliknya peningkatan nilai PBV dapat menunjukkan bahwa pasar semakin percaya pada prospek perusahaan. (Uzliawati et al. 2016). Nilai perusahaan dapat dicapai dengan meningkatkan kinerja keuangan. Ketika seseorang akan berinvestasi salah satu faktor yang dianalisa adalah kinerja keuangan, apakah investasi yang ditanamakan akan menguntungkan atau tidak. Kinerja keuangan dapat dilihat dari laporan keuangan yang dikeluarkan perusahaan (Yulianti et al. 2020). Para analis atau investor menggunakan informasi keuangan yang telah disediakan perusahaan dengan menghitung rasio-rasio likuidtas, leverage, aktivitas dan profitabilitas perusahaan sebagai dasar pertimbangan dalam keputusan berinvestasi (Mahendra et al. 2012).

Penilaian terhadap aspek keuangan berdasarkan Surat Keutusan Kementerian BUMN Nomor KEP-100/MBU/2002 menggunakan 8 indikator rasio keuangan. Agar tetap mendorong perusahaan ke arah peningkatan daya saing dan efisiensi kinerja keuangan perusahaan digambarkan melalui penilaian kesehatan keuangan. Didasarkan pada teori signal bahwa sinyal yang diberikan manajer dapat dijadikan petunjuk kualitas suatu perusahaan. Teori sinyal merupakan tanda atau sinyal yang diberikan kepada 
investor berupa berbagai informasi kinerja perusahaan yang dapat digunakan untuk pengambilan keputusan dengan baik dan dapat mempengaruhi nilai suatu perusahaan (Putri et al. 2016).

Penelitian ini membahas perusahaan BUMN pada sektor bidang konstruksi, terdapat sebanyak 4 emiten plat merah, yaitu PT. Adhi Karya (Persero) Tbk., PT. Pembangunan Perumahan (Persero) Tbk. PT. Waskita Karya (Persero) Tbk., dan PT. Wijaya Karya (Persero) Tbk. Berdasarkan latar belakang diatas penelitian ini dimaksudkan untuk mengetahui kinerja keuangan perusahaan sesuai dengan indikator tingkat penilaian kesehatan berdasarkan Surat Keputusan Menteri BUMN Nomor: KEP100/MBU/2002 perusahaan BUMN terhadap nilai perusahaan bidang konstruksi yang terdaftar di Bursa Efek Indonesia pada periode tahun 2016-2019.

\section{Badan Usaha Milik Negara (BUMN)}

Pemerintah berupaya untuk mewujudkan terpenuhinya hajat hidup seluruh Rakyat Indonesia, Pemerintah menetapkan sejumlah peraturan sebagai landasan dan acuan dalam kebijakan pembinaan BUMN (Sekretariat Kementerian BUMN 2019) sebagai berikut:

1. UUD 45 pasal 33 ayat 2 dan ayat 3 "Cabang-cabang produksi yang penting bagi Negara dan yang menguasai hajat hidup orang banyak dikuasai oleh Negara";

2. Undang-Undang (UU) Nomor 19 Tahun 2003 tentang Badan Usaha Milik Negara;

3. UU Nomor 40 Tahun 2007 tentang Perseroan Terbatas, protokol pasar modal (paket UU Pasar Modal dan peraturan pelaksanaannya khusus bagi BUMN yang tercatat di Bursa Efek Indonesia);

4. Paket UU Keuangan Negara; dan

5. Paket UU Pemeriksaan dan Pengawasan.

Maksud dan tujuan pendirian BUMN yaitu sebagai berikut:

1. Memberikan sumbangan bagi perkembangan perekonomian nasional pada umumnya dan penerimaan negara pada khususnya.

2. Mengejar keuntungan.

3. Menyelenggarakan kemanfaatan umum berupa penyediaan barang dan/atau jasa yang bermutu tinggi dan memadai bagi pemenuhan hajat hidup orang banyak.

4. Menjadi perintis kegiatan-kegiatan usaha yang belum dapat dilaksanakan oleh sektor swasta dan koperasi.

5. Turut aktif memberikan bimbingan dan bantuan kepada pengusaha golongan ekonomi lemah, koperasi, dan masyarakat.

\section{Teori Sinyal (Signaling Theory)}

Pemberian sinyal merupakan langkah kegiatan yang dilakukan pihak manajemen perusahaan untuk memberikan petunjuk kepada investor bagaimana pandangan manajemen mengenai prospek perusahaan (Brigham \& Houston 2015). 


\section{Kinerja Keuangan}

Kinerja keuangan menurut Rudianto (2013) merupakan hasil atau prestasi yang dapat dicapai oleh manajemen perusahaan dalam menjalankan fungsinya mengelola aset perusahaan untuk mengetahui dan mengavaluasi sampai di mana tingkat keberhasilan perusahaan berdasarkan aktivitas keuangan yang telah dilaksanakan. Pengukuran kinerja adalah suatu proses penilaian kemajuan pekerjaan terhadap tujuan dan sasaran yang telah ditentukan sebelumnya dan dapat digunakan sebagai alat untuk meningkatkan kualitas pengambilan keputusan dan akuntabilitas. (Sekretariat Kementerian BUMN 2019).

Berdasarkan Keputusan Menteri Badan Usaha Milik Negara Nomor: KEP-100/MBU/2002, maka ditentukan bobot yang berbeda antara BUMN infrastruktur dan BUMN non infrastruktur dalam menilai keberhasilan BUMN pada aspek keuangan. Total bobot pada BUMN non infrastruktur adalah 70, sedangkan bobot pada BUMN infrastruktur adalah 50. Penilaian aspek keuangan dengan indikator dapat dilihat pada tabel 1 .

Tabel 1. Daftar Indikator Aspek Keuangan

\begin{tabular}{|c|c|c|}
\hline No & Indikator & Rumus \\
\hline 1. & $\begin{array}{l}\text { Imbalan Kepada Pemegang } \\
\text { Saham (ROE) }\end{array}$ & $R O E=\frac{\text { Laba setelah Pajak }}{\text { Modal Sendiri }} \times 100 \%$ \\
\hline 2. & Imbalan Investasi (ROI) & $R O I=\frac{E B I T+\text { Penyusutan }}{\text { Capital Employed }} \times 100 \%$ \\
\hline 3. & Rasio Kas & $\begin{array}{l}\text { Cash Ratio } \\
=\frac{\text { Kas }+ \text { Bank }+ \text { Surat Berharga Jangka Pendek }}{\text { Current Liabilities }} \times 100 \%\end{array}$ \\
\hline 4. & Rasio Lancar & Current Ratio $=\frac{\text { Current Asset }}{\text { Current Liabilities }} \times 100 \%$ \\
\hline 5. & Colection Periods & $C P=\frac{\text { Total Piutang Usaha }}{\text { Total Pendapatan Usaha }} \times 365$ Hari \\
\hline 6. & Perputaran Persediaan & $P P=\frac{\text { Total Persediaan }}{\text { Total Pendapatan Usaha }} \times 365$ Hari \\
\hline 7. & Perputaran Total Asset & TATO $=\frac{\text { Total Pendapatan }}{\text { Capital Employed }} \times 100 \%$ \\
\hline 8. & $\begin{array}{l}\text { Rasio Modal Sendiri } \\
\text { Terhadap Total Aktiva }\end{array}$ & TMS terhadap $T=\frac{\text { Total Modal Sendiri }}{\text { Total Asset }} \times 100 \%$ \\
\hline
\end{tabular}

\section{Nilai Perusahaan}

Nilai perusahaan merupakan keadaan yang telah dicapai oleh perusahaan sebagai gambaran masyarakat terhadap kepercayaan kepada perusahaan melalui proses kegiatan dalam periode tertentu, berawal dari perusahaan didirikan hingga saat ini (Muid 2012). 


\section{Kinerja Keuangan Terhadap Nilai Perusahaan}

Semakin baik kinerja keuangan dari sebuah perusahaan maka semakin tinggi kemampuan perusahaan dalam menghasilkan keuntungan.

H1: Kinerja keuangan berpengaruh positif signifikan terhadap nilai perusahan

\section{METODE RISET}

\section{Jenis dan Sumber Penelitian}

Penelitian bersifat kuantitatif dengan jenis data yang digunakan merupakan data sekunder berupa laporan keuangan perusahaan BUMN di Bursa Efek Indonesia (BEI) yang telah dipublikasikan periode 2016-2019 dengan metode pengumpulan data menggunakan metode studi kepustakaan dan studi observasi. Sumber data yang digunakan berasal dari laporan keuangan perusahaan, sample yang digunakan terdaftar dalam Indonesia Capital Market Directory (ICMD), Bursa Efek Indonesia (BEI) atau pada website perusahaan.

Dalam penelitian ini jumlah populasi terdiri dari 4 perusahaan BUMN di bidang konstruksi yang terdaftar di BEI periode 2016-2019 serta dokumen laporan keuangan tahunan yaitu PT. Adhi Karya (Persero) Tbk., PT. Pembangunan Perumahan (Persero) Tbk., PT. Wijaya Karya (Persero) Tbk., dan PT. Waskita Karya (Persero) Tbk. Penelitian ini menggunakan jenis data sekunder yaitu sumber data yang tidak langsung memberikan data kepada pengumpul data, merupakan data yang bersifat mendukung keperluan data primer diantaranya buku-buku, bacaan dan literatur yang menjadi penunjang dan berkaitan dengan penelitian Sugiyono (2017). Teknik pengumpulan data yaitu dokumentasi mencari data mengenai variabel yang berupa catatan, transkrif, buku, surat kabar, majalah, prasasti, notulen rapat, agenda dan sebagainya (Arikunto 2006).

\section{Analisis Data}

Berdasarkan penilaian terhadap kinerja perusahaan, salah satunya adalah kinerja keuangan perusahaan. Aspek keuangan yaitu penilaian kinerja dengan menggunakan analisis rasio keuangan seperti ditetapkan oleh Kementerian BUMN. Berdasarkan Surat Keputusan Menteri BUMN Nomor: KEP-100/MBU/2002 non infrastruktur. Data kuantitatif yang diperoleh selanjutnya dilakukan analisis melalui beberapa tahapan sebagai berikut:

1. Menghitung masing-masing rasio sesuai SK Menteri Negara BUMN Nomor:KEP100/MBU/2002.

2. Menentukan bobot masing-masing rasio yang telah ditentukan oleh SK Menteri Negara BUMN Nomor:KEP-100/MBU/2002.

3. Menentukan skor kategori penilaian tingkat kesehatan BUMN. Rumus total skor sebagai berikut:

$$
\text { Total Skor }=\frac{\text { Akumulasi Bobot Indikator }}{\text { Total Bobot Standar }} \times 100
$$


Setelah data-data dari berbagai sumber tersebut dikumpulkan, kemudian selanjutnya diolah dengan menggunakan anallisis Structural Equation Modeling (SEM) pengolahan data pada perusahaan konstruksi BUMN go public yang tercatat pada Bursa Efek Indonesia periode 2016-2019 selanjutnya diolah menggunakan program excel dan SmartPLS 3.0.

\section{Evaluasi Outer Model}

Pengujian pertama yang dilakukan adalah pengujian outer model yaitu untuk memastikan bahwa measurement yang digunakan layak untuk dijadikan pengukuran (valid dan reliable). Kriteria pengujian didasarkan pada Ghozali (2014). Uji yang dilakukan pada outer model yaitu convergent validity, discriminant validity dan unidimensional validity (Hussein 2015). Convergent validity dilakukan dengan melihat nilai loading factor pada variabel laten dengan indikatornya masing-masing, dalam penelitian ini adalah indikator reflektif.

Analisis yang dilakukan pada model awal penelitian menunjukkan bahwa indikator $\mathrm{CP}(0.620)$, PP (-0.100), ROE (-0.535), ROI (0.408) dan TATO (-0.346) memiliki nilai loading factor di bawah 0.70 . Oleh sebab itu kelima indikator tersebut harus dikeluarkan dari model sehingga didapatkan model yang tidak menunjukkan nilai loading factor dibawah 0.70. Selanjutnya dengan melihat nilai Average Variance Extracted (AVE), nilai AVE yang diharapkan adalah 0.50 (Ghozali 2014). Hasil nilai AVE masing-masing konstruk sudah berada di atas 0.50 yaitu kinerja perusahaan (0.853) dan nilai perusahaan (0.844) maka dapat dikatakan tidak ada permasalahan convergent validity pada model yang diuji. Sehingga pengujian dapat dilanjutkan pada langkah berikutnya yaitu uji discriminant validity. Discriminant validity dapat diuji dengan membandingkan nilai akar kuadrat AVE dengan nilai korelasi antar konstruk.

Bahwa nilai akar kuadrat AVE masing-masing konstruk yaitu kinerja perusahaan (0.924) dan nilai perusahaan (0.919) lebih besar dari kolerasi masing-masing konstruk. Metode lain yang dapat digunakan untuk menguji discriminant validity adalah dengan melihat tabel cross loading. Nilai cross loading digunakan untuk mengetahui apakah konstruk memiliki diskriminan yang memadai yaitu dengan cara membandingkan nilai loading pada konstruk yang dituju harus lebih besar dibandingkan dengan nilai loading konstruk yang lain menggambarkan bahwa seluruh konstruk dalam model sudah memiliki composite reliability lebih dari 0.70 dan pada nilai cronbach's alpha konstruk kinerja perusahaan (0.915) dan nilai perusahaan (0.824) memiliki nilai diatas 0.60 sehingga dapat dipastikan bahwa model sudah valid. 


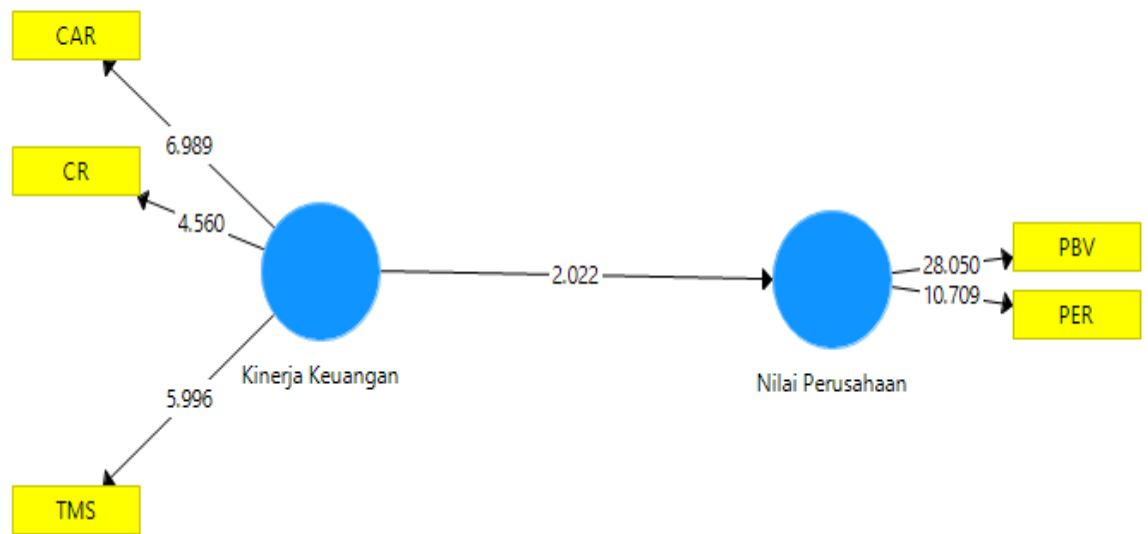

Gambar 1. Hasil Analisis Model Akhir

\section{Evaluasi Inner Model}

Pengujian kedua yang dilakukan sebagai bentuk perbaikan model adalah pengujian inner model atau model struktural. Pengujian inner model dilakukan untuk memastikan bahwa model struktural yang dibangun robust dan akurat. Evaluasi inner model merupakan analisis yang menggambarkan hubungan antar variabel, apakah terdapat pengaruh positif atau negatif. Pada inner model, pengujian dilakukan terhadap 2 kriteria yaitu R2 dari variabel laten endogen dan estimasi koefisien jalur (Ghozali 2014). Hasil pengujian R2 dari variabel laten endogen menunjukkan seberapa besar variabilitas variabel laten endogen dapat dijelaskan oleh variabilitas laten eksogen.

Nilai R2 pada pengaruh kinerja perusahaan terhadap nilai perusahaan sebesar 0.286 dapat diartikan bahwa kemampuan variabel kinerja perusahaan sebesar 28,6 persen sedangkan 71.4 persen dijelaskan oleh variabel lain yang tidak termasuk dalam penelitian ini. Selanjutnya adalah uji estimasi koefisien jalur dengan membandingkan nilai t-statistik pada output bootstrapping untuk menilai pengaruh signifikan suatu konstruk dan nilai path coefficient untuk melihat seberapa besar pengaruhnya. Pada penelitian ini taraf nyata yang digunakan adalah 5 persen. Pengaruh signifikan positif ditunjukkan dengan syarat nilai $t$ hitung $>\mathrm{t}$ tabel $=1.96$, Selain itu dapat ditujukan pula dengan nilai p-value, dimana jika p-value $<0.05$. (Tabel 2)

Tabel 2. Hasil Pengujian Bootstrapping Inner Model

\begin{tabular}{cccccc}
\hline No & Pengaruh & Original Sample & T Statistik & P Value & Hasil Pengujian \\
\hline 1 & $\begin{array}{c}\text { Kinerja perusahaan- } \\
\text { Nilai perusahaan }\end{array}$ & 0.535 & 2.022 & 0.044 & $\begin{array}{c}\text { Positif } \\
\text { signifikan }\end{array}$ \\
\hline \multicolumn{5}{c}{ Sumber : Olahan penulis }
\end{tabular}

\section{HASIL PENELITIAN DAN PEMBAHASAN}

Berdasarkan Surat Keputusan Menteri BUMN Nomor: KEP 100/MBU/2002. Dari hasil analisis yang telah dilakukan berdasarkan aspek keuangan terdiri dari delapan indikator atau rasio, maka 
diperoleh hasil penilaian, 4 perusahaan BUMN di bidang konstruksi yang terdaftar di BEI periode 20162019 yaitu:

1. Kinerja Keuangan PT. Adhi Karya (Persero) Tbk.

Berdasarkan hasil penilaian tingkat kesehatan aspek keuangan dapat diketahui tingkat kesehatan aspek keuangan PT. Adhi Karya (Persero) Tbk periode 2016-2019. Pada tahun 2016 sampai dengan tahun 2019 selama 4 tahun berturut-turut PT. Adhi Karya (Persero) Tbk. tetap mempertahankan kategori BBB dengan predikat kurang sehat. Total skor sebesar 59 pada tahun 2016, selanjutnya pada tahun 2017 dan tahun 2018 mendapat skor 64 selanjutnya pada tahun 2019 PT Adhi Karya (Persero) Tbk mengalami penurunan nilai total skor dengan hanya mendapat total skor 58 namun kategori predikat tidak mengalami perubahan yaitu tetap kurang sehat.

2. Kinerja Keuangan PT. Pembangunan Perumahan (Persero) Tbk.

Berdasarkan hasil penilaian tingkat kesehatan aspek keuangan dapat diketahui tingkat kesehatan aspek keuangan PT. Pembangunan Perumahan (Persero) Tbk periode 2016-2019. Selama tiga tahun berturut-turut sejak tahun 2016 sampai dengan tahun 2018 tetap mempertahankan total skor masing- masing 73, dengan kategori A dan mendapat predikat sehat. Sedangkan pada tahun 2019 PT. Pembangunan Perumahan (Persero) Tbk mengalami peningkatan total skor dengan mendapat total skor 81 dengan kategori AA namun kategori predikat tidak mengalami perubahan yaitu sehat. Kinerja Keuangan PT. Waskita Karya (Persero) Tbk.

3. Kinerja Keuangan PT. Waskita Karya (Persero) Tbk.

Berdasarkan hasil penilaian tingkat kesehatan aspek keuangan dapat diketahui tingkat kesehatan aspek keuangan PT. Waskita Karya (Persero) Tbk. periode 2016-2019. Pada tahun 2016, PT. Waskita Karya (Persero) Tbk mendapat total skor 68 dalam kategori A dengan predikat sehat. Selanjutnya pada tahun 2017 dan tahun 2018 PT. Waskita Karya (Persero) Tbk mengalami peningkatan dengan total skor 69 dan 71 dengan masing-masing mendapat kategori A, dan tetap dalam kategori predikat sehat. Kemudian, pada tahun 2019 PT. Waskita Karya (Persero) Tbk, mengalami penurunan nilai total skor dengan mendapat total skor hanya 46 dengan penurunan kategori yaitu BB dan mendapat predikat kurang sehat

4. Kinerja Keuangan PT. Wijaya Karya (Persero) Tbk.

Berdasarkan hasil penilaian tingkat kesehatan aspek keuangan dapat diketahui tingkat kesehatan aspek keuangan PT Wijaya Karya (Persero) Tbk periode 2016-2019. Pada tahun 2016, PT Wijaya Karya (Persero) Tbk mendapat total skor 59 dalam kategori BBB dengan predikat kurang sehat. Selanjutnya pada tahun 2017 dan 2018 PT Wijaya Karya (Persero) Tbk mengalami peningkatan dengan total skor masing-masing 64 namun tetap pada kategori BBB, dengan predikat kurang sehat. Kemudian, pada tahun 2019 PT. Wijaya Karya (Persero) Tbk 
mengalami penurunan kembali dengan mendapat total skor 58 dengan tetap mendapat kategori BBB dan berada pada predikat kurang sehat.

\section{Pengaruh Kinerja Perusahaan terhadap Nilai Perusahaan}

Pengujian hipotesis menunjukkan hasil bahwa kinerja keuangan perusahaan berpengaruh terhadap nilai perusahaan, dapat dilihat pada t-hitung $>\mathrm{t}$-tabel. Dilihat dari nilai original samplenya sebesar 0.535 pengaruh nyata bersifat positif maka dapat dikatakan bahwa semakin tinggi kinerja keuangan perusahaan maka akan semakin tinggi nilai perusahaan sesuai dengan penelitian Sukendro dan Pujiharjanto (2012) dan Wibowo (2017) yaitu memberikan pemahaman kepada manajemen jika kinerja keuangan perusahaan naik maka akan menyebabkan meningkatnya pendapatan perusahaan sehingga laba perusahaan juga meningkat. Naiknya laba perusahaan menjadi sinyal positif bagi investor, sehingga diharapkan harga saham akan mengalami kenaikan.

Hasil penelitian ini sesuai dengan penelitian Mahendra et. al. (2012) yang menunjukkan pengaruh kinerja keuangan berpengaruh positif terhadap nilai perusahaan. Kemampuan kas yang tinggi akan berdampak terhadap kemampuan kewajiban jangka pendek perusahaan dan berdampak positif terhadap nilai perusahaan. Berbeda dengan penelitian yang dilakukan Hermawan dan Maf'ulah (2014) dengan hasil menunjukkan bahwa secara parsial variabel kinerja keuangan tidak berpengaruh secara signifikan terhadap nilai perusahaan

\section{KESIMPULAN DAN SARAN}

\section{Kesimpulan}

Hasil perhitungan yang diperoleh dari delapan indikator rasio dalam kinerja aspek keuangan berdasarkan Keputusan Menteri BUMN No: Kep-100/MBU/2002 untuk menilai tingkat kesehatan dalam aspek keuangan pada 4 perusahaan BUMN di bidang konstruksi yang terdaftar di BEI periode 2016-2019. Berdasarkan hasil analisis data dapat ditarik kesimpulan:

1. PT. Adhi Karya (Persero) Tbk, pada periode 2016-2019 menunjukkan perusahaan mendapatkan predikat Kurang Sehat kategori BBB.

2. Hasil penilaian kinerja keuangan PT. Pembangunan Perumahan (Persero) Tbk, pada periode 2016-2019 menunjukkan bahwa perusahaan mendapatkan predikat Sehat kategori A, pada tahun 2016 sampai tahun 2018. Selanjutnya pada tahun 2019 perusahaan dengan tetap mendapat predikat Sehat kategori AA.

3. Hasil penilaian kinerja keuangan PT. Waskita Karya (Persero) Tbk, pada periode 2016-2019 menunjukkan bahwa perusahaan mendapat predikat Sehat kategori A pada tahun 2016 sampai tahun 2018. Selanjutnya pada tahun 2019 perusahaan mendapat predikat Kurang Sehat kategori BB.

4. Hasil penelitian kinerja keuangan PT. Wijaya Karya (Persero) Tbk, pada periode 2016-2019 menunjukkan bahwa perusahaan mendapat predikat Kurang Sehat kategori BBB. 
5. Nilai perusahaan positif signifikan dipengaruhi oleh kinerja perusahaan, bahwa kinerja keuangan memberikan sinyal kepada nilai perusahaan.

\section{Saran}

Berdasarkan hasil penelitian maka terdapat saran antara lain:

1. Bagi perusahaan, berdasarkan perkembangan kinerja keuangan keempat perusahaan konstruksi BUMN pada periode 2016-2019 pada akumulasi bobot penilaian diharapkan perusahaan dapat mempertahankan konsistensi yang sudah baik menjadi lebih baik lagi dan dapat lebih meningkatkan kinerja keuangan perusahaan.

2. Bagi investor, pada perusahaan BUMN sebaiknya pengambilan keputusan investasi tidak hanya didasarkan pada penilaian kinerja keuangan namun dapat lebih tepat menganalisis informasi yang berkembang sehingga dapat dijadikan pertimbangan dalam pengambilan keputusan.

3. Bagi penelitian berikutnya, penelitian ini hanya memasukkan aspek keuangan, diharapkan pada penelitian selanjutnya penilaian kinerja BUMN dapat memasukkan aspek operasional dan aspek administrasi sehingga penelitian dapat dilihat secara aspek keseluruhan, berdasarkan Surat Keputusan Menteri BUMN Nomor:KEP-100/MBU/2002. 


\section{DAFTAR PUSTAKA}

Arikunto, S. (2006). Metode Penelitian Kualitatif. Jakarta: Bumi Aksara

Brigham, E.F. dan Houston, J. F. (2015). Fundamentals of Financial Management, Concise Eighth Edition. USA: Cengange Learning.

Dinarjito, A. (2018). Menilai Kesehatan BUMN Konstruksi Yang Terdaftar Di Bursa Efek Indonesia Sebagai Akibat Meningkatnya Proyek Infrastruktur Pemerintah. Subtansi, 2(1), 1-18.

Ghozali, I. (2014). Structural Equation ModellingMetode Alternatif Dengan Partial Least Square (PLS). Semarang (ID): Universitas Diponegoro.

Hermawan, S., dan Maf'ulah, A.N. (2014). Pengaruh Kinerja Keuangan Terhadap Nilai Perusahaan Dengan Pengungkapan Corporate Social Responsibility Sebagai Variabel Pemoderasi. Jurnal Dinamika Akuntansi. 6(2). 103-118.

Hussein, A.S. (2015). Modul Ajar Penellitian Bisnis dan Manajemen Menggunakan Partial Least Square (PLS) dengan SmartPLS 3.0. Jurusan Manajemen Fakultas Ekonomi dan Bisnis Universitas Brawijaya.

IDX. (2020). www.idx.co.id. Diakses: 22 November 2020.

Investor Daily Indonesia. (2017). Diakses dari: https://investor.id/editorial/kebangkitan-konstruksi. Diakses: 14 November 2020.

Mahendra, A., Artini, L.G.S., dan Suarjaya, A.A.G. (2012). Pengaruh Kinerja Keuangan Terhadap Nilai Perusahaan Pada Perusahaan Manufaktur Di Bursa Efek Indonesia. Jurnal Manajemen, Strategi Bisnis dan Kewirausahaan. 6(2). 130-138.

Muid, A.M.R.N. (2012). Pengaruh Faktor Internal dan Eksternal Perusahaan Terhadap Nilai Perusahaan (Studi Empiris Pada Perusahaan Manufaktur Yang Terdaftar Di Bursa Efek Indonesia Periode 2007-2010). Jurnal Akuntansi. 1(2). 4

Putri, R. W., Ukhriyawati, C. F. (2016). Pengaruh Likuiditas, Leverage dan Profitabilitas Terhadap Nilai Perusahaan pada Perusahaan Telekomunikasi yang Terdaftar di Bursa Efek Indonesia Tahun 2012-2014. Jurnal Bening, 3(1), 52-73. 
Resti, A.A. (2021). Penilaian Kinerja Keuangan terhadap Nilai Perusahaan BUMN ....

Rudianto. (2013). Akuntansi Manajemen Informasi Untuk Pengambilan Keputusan Strategis. Jakarta: Erlangga.

Sekretariat Kementerian BUMN. (2019). Laporan Kinerja Kementerian Badan Usaha Milik Negara .https://bumn.go.id/storage/report/sL49fPYAUnuQPAr17UGsnf6e84dS5VCI5XV1b1Qh.pdf. Diakses: 21 November 2020

Sugiyono. (2017). Metode Penelitian Kuantitatif, Kualitatif. Bandung: Alfabeta, CV.

Undang-Undang Republik Indonesia No.18 tahun 1999 tentang Usaha Konstruksi. Kementrian Badan Usaha Milik Negara, 2002, KEP - 100/MBU/2002, Jakarta. Diakses dari: http://jdih.bumn.go.id/baca/KEP-100/MBU/2002.pdf. Diakses 14 November 2020.

Utamaningsih, A. dan Muharis, C. (2020). Evaluasi Kinerja Keuangan Perusahaan Konstruksi BUMN 2015-2018. Jurnal Ilmiah Rekayasa Sipil, 17(1), 75-86.

Uzliawati, L., Nofianti, N., dan Ratnasari, D.P. (2016). Struktur Modal, Investmrnt Opportunity Set, Likuiditas dan Nilai Perusahaan. Jurnal Keuangan dan Perbankan. 20(2), 195-203.

Wibowo, A. (2012). Peran Kinerja Perusahaan Dan Risiko Sistematis Dalam Menentukan Pengaruh Inflasi Terhadap Nilai Perusahaan. Jurnal Media Ekonomi dan Manajemen. 26(2), 1-18.

Yulianti, I., Enas. dan Setiawan, I. (2020). Pengaruh Kinerja Keuangan Terhadap Nilai Perusahaan (Suatu Studi Pada. Bank BNI yang Terdaftar di BEI periode 2008-2017. Business Management and Entrepreneurship Journal. 2(2), 60-70. 